\title{
RBM15 wt Allele
}

National Cancer Institute

\section{Source}

National Cancer Institute. RBM15 wt Allele. NCI Thesaurus. Code C97294.

Human RBM15 wild-type allele is located in the vicinity of $1 \mathrm{p} 13$ and is approximately $8 \mathrm{~kb}$ in length. This allele, which encodes putative RNA-binding protein 15, is involved in binding to RNA. A chromosomal translocation $\mathrm{t}(1 ; 22)(\mathrm{p} 13 ; \mathrm{q} 13)$ of this gene and the MKL1 gene is associated with acute megakaryoblastic leukemia. 